\title{
The relationship between queen execution and cuticular hydrocarbons in stingless bee Melipona scutellaris (Hymenoptera: Meliponini)
}

\author{
Edmilson Amaral de Souza ${ }^{1} \cdot$ José R. Trigo $^{2} \cdot$ Douglas E. Santos $^{3} \cdot$ \\ Carlos U. Vieira ${ }^{4} \cdot$ José E. Serrão $^{3}$
}

Received: 11 April 2016/Accepted: 3 November 2016 / Published online: 12 November 2016

(C) Springer International Publishing 2016

\begin{abstract}
In queenright colonies of stingless bees of the genus Melipona, workers recognize, attack, and kill young virgin queens. For Melipona scutellaris, we observed that virgin queens were executed when they were between 5 and 9 days old, while newly emerged queens were not attacked. The faster movements of old virgin in relation to newly emerged might be responsible for attacks. It has been also hypothesized that cuticular hydrocarbons are the source of the signal used by workers to recognize virgin queens. We investigated whether newly emerged, 8 days old virgin and physogastric queens of $M$. scutellaris have different cuticular hydrocarbon profiles. Cuticular hydrocarbons of three ages were compared using gas chromatography-mass spectrometry. The cuticular hydrocarbon profiles varied by reproductive status and age. Changes in the cuticular hydrocarbons in virgin queens during aging suggest that these compounds, together with change in movement, may play a role in the recognition of virgin queens by workers prior to regicide.
\end{abstract}

Handling Editor: Günther Raspotnig.

Edmilson Amaral de Souza

edmilson.souza@ufv.br

1 Instituto de Ciências Biológicas e da Saúde, Universidade Federal de Viçosa, 38810-000 Rio Paranaíba, Minas Gerais, Brazil

2 Departamento de Biologia Animal, Instituto de Biologia, Universidade Estadual de Campinas, 13083-970 Campinas, São Paulo, Brazil

3 Departamento de Biologia Geral, Universidade Federal de Viçosa, 36570-000 Viçosa, Minas Gerais, Brazil

4 Laboratório de Genética, Instituto de Genética e Bioquímica, Universidade Federal de Uberlândia, Uberlândia, Minas Gerais, Brazil
Keywords Regicide - Attractiveness · Virgin queens · Worker attacks

\section{Introduction}

Meliponini are highly eusocial bees with two female castes: the queens are responsible for reproduction, and the workers carry out the colony's maintenance tasks (Michener 1974). In species of the genus Melipona, virgin queens are smaller than the workers and unlike other species of eusocial bees, there is a continuous production of queens across the colony's lifespan. Virgin queens represent 4-7 \% of the colony (Imperatriz-Fonseca and Zucchi 1995; Koedam 1999; Sommeijer et al. 2003; Santos-Filho et al. 2006). The main explanation for the high production of queens was as a nest maintenance strategy due to physogastric queen mortality (Engels and Imperatriz-Fonseca 1990; Koedam et al. 1995), or as a future supply for the hive (Koedam et al. 1995). Sommeijer et al. (2003) reported that a considerable proportion of excess queens are not eliminated by the workers but manage to safely leave the nest. They hypothesized that worker fitness was increased by the departure of the excess virgin queens when they reproduce outside their maternal nest.

Triggers are needed for workers to initiate queen execution. Behavior and appearance of virgin queens, including fast body movements, rhythmic wing movements, and an enlarged abdomen, which changes with the queen's age, may encourage workers to attack and subsequently kill them (Silva et al. 1972; Kleinert and Imperatriz-Fonseca 1994; Jarau et al. 2009). Generally, Melipona queens mate with a single male when they are 3-8 days old (Kerr et al. 1962; Silva et al. 1972), while 
excess virgin queens are killed by workers at this age (Imperatriz-Fonseca and Zucchi 1995). In M. quadrifasciata colonies with physogastric queens for example, newly emerged queens are not attacked by workers. However, when they reach 3-8 days of age, they begin to move more quickly around the nest, requesting food from workers through antennae contact (Imperatriz-Fonseca and Zucchi 1995). This behavior is likely related to an attempt to be accepted as a new queen (Silva et al. 1972; Van Veen et al. 1999). These virgin queens are attacked and killed or driven from the colony by the workers (Kerr et al. 1962). In $M$. marginata and $M$. beecheii, workers also kill the most active virgin queens, while ignoring queens that move less (Kleinert and Imperatriz-Fonseca 1994; Imperatriz-Fonseca and Zucchi 1995; Van Veen et al. 1999; Jarau et al. 2009).

On the other hand, differences in cuticular hydrocarbons (CHs) produced by virgin queens of different ages might be involved in their recognition by workers. Such age-dependent recognition was reported for the honey bee Apis mellifera capensis, where the response of workers toward introduced virgin queens showed a significant increase in hostile reactions as queens aged (Wossler et al. 2006). These authors showed that worker reactions were related to the relative production of $(E)$-9-oxodec-2-enoic acid in the queen's mandibular gland secretions. In fact, queens and workers of the stingless bees have different $\mathrm{CH}$ profiles, suggesting an important role for these substances in the recognition of an individual nestmate (Abdalla et al. 2003; Kerr et al. 2004; Ferreira-Caliman et al. 2010; Monnin 2006; Nunes et al. 2009a, b, 2014). However, no study has related virgin queen $\mathrm{CH}$ profiles at different ages to queen execution. The stingless bee Melipona scutellaris is of particular importance because it appears as "endangered" on the Brazilian agency ICMBio's red list. Therefore, behavioral studies are important for future management of this threatened stingless bee. We collected two colonies of M. scutellaris in 2007 and started studies of its biology (Sousa et al. 2013; Santos et al. 2015). We here show that excess virgin queens are killed by workers, a phenomenon triggered by a change in $\mathrm{CHC}$ profiles of virgin queens during the first days of their life.

\section{Materials and methods}

\section{Stingless bees}

We keep M. scutellaris colonies in the Central Apiary of the Federal University of Viçosa, Viçosa, state of Minas Gerais, Brazil. Bees were obtained from two queenright colonies. Brood combs were transferred to wooden boxes $(20 \times 20 \times 10 \mathrm{~cm})$ maintained at $29-30{ }^{\circ} \mathrm{C}$ and observed daily to verify the emergence of queens. The newly emerged queens were marked on the thorax with non-toxic paint of different colors according to their date of emergence. These virgin queens were returned to the nest from which the brood comb was obtained. These nests were observed daily for $1 \mathrm{~h}$ throughout the day to ascertain the interactions between workers and the virgin queens, as well as to determine the age of dead virgin queens. Another set of brood combs was used for $\mathrm{CH}$ studies of virgin queens with different ages.

\section{Behavioral interactions between workers and virgin queens}

Worker/virgin queen behavioral interaction was observed until workers attacked and killed the virgin queens. This generated $300 \mathrm{~h}$ of observation for the 30 virgin queens. To verify whether virgin queen deaths were due to attack or natural causes, their carcasses were examined for signs of aggression, such as decapitation.

\section{Analysis of cuticular hydrocarbons}

Virgin queens were collected in two queenright colonies as described above. To sample virgin queens at the age when they were killed, we chose 8-day-old virgin queens, given that between 5 and 9 days after emergence, theses queens were executed by workers. Newly emerged virgin queens were placed in a protective metal grid cage with nurse workers, pollen, and honey ad libitum, and then kept in the colonies from which they were obtained for 8 days. On the other hand, two physogastric queens from the two queenright colonies were used for $\mathrm{CH}$ analysis. For the other bees, three individuals each were sampled from the same colony.

CHs were extracted individually by immersing the bees in $500 \mu \mathrm{L}$ of hexane in glass vials for $10 \mathrm{~min}$. The bees were removed with tweezers, and the hexane was evaporated in an $\mathrm{N}_{2}$ flow. The samples were then diluted in $50 \mu \mathrm{L}$ of hexane for analysis by gas chromatography-mass spectrometry (GC-MS). This analysis was performed using a gas chromatograph (Hewlett Packard 6890) equipped with a fused silica capillary column (HP-5MS $5 \%$ phenyl $95 \%$ methyl siloxane $30 \mathrm{~m} \times 250 \mu \mathrm{m} \times 0.25 \mu \mathrm{m}$, Hewlett Packard), coupled directly with a selective mass detector (Hewlett Packard 5973) set to electron impact mode. All analyses were performed under the following conditions: the injected volume was $1 \mu \mathrm{L}$ at $270{ }^{\circ} \mathrm{C}$ in splitless mode; the temperature program used was $60-230{ }^{\circ} \mathrm{C}$ at $20{ }^{\circ} \mathrm{C} / \mathrm{min}, 230-300{ }^{\circ} \mathrm{C}$ at $2{ }^{\circ} \mathrm{C} / \mathrm{min}$, and $300{ }^{\circ} \mathrm{C}$ for $10 \mathrm{~min}$; the carrier gas He was set to $1.2 \mathrm{~mL} /$ min; ionization energy was $70 \mathrm{eV}$ and a range of 40-600 amu. CHs were identified by their retention index when co- 
injected with $n$-alkanes in accordance with van den Dool and Kratz (1963), together with fragmentation patterns (Carlson et al. 1998, 1999; Nelson et al. 1981; Pomonis 1989). The positions of double alkene bonds were not assigned. The relative abundance of each peak in the chromatogram was calculated as follow: the relative abundance of single peaks in relation to the peak with the highest area was calculated. The peaks lower than $5 \%$ in this relative abundance were discarded. For the remained peaks, the relative abundance was calculated in relation to the chromatogram total area.

\section{Statistical analysis}

A nonparametric, distance-based, permutational analysis of variance (PERMANOVA), using the Bray-Curtis dissimilarity, was carried out to verify if $\mathrm{CH}$ profiles differed between physogastric, newly emerged virgin, and 8-dayold virgin queens (Anderson 2005). The pairwise comparison among the three queen groups was assessed by Monte Carlo P-Values, $\mathrm{P}(\mathrm{MC})$, given that the low number of groups (three) and low number of replications in each group (two or three) limited the number of possible permutations (Anderson 2005). Together, non-metric multidimensional scaling (NMDS) was carried out to produce an ordination of queen categories based on the BrayCurtis dissimilarity matrix (Legendre and Legendre 2003).

\section{Results}

\section{Behavioral interactions between workers and virgin queens}

Of 30 dead virgin queens analyzed, 23 were conclusively determined to have been killed by workers, while the remaining 7 were found dead but showed no signs of aggression. The 23 queens were executed when they were 5-9 days old (median 7 days).

Newly emerged queens moved slowly, but were more active than newly emerged workers, which were almost immobile. Initially, virgin queens were found restricted to the region near the brood combs, performing slow movements, which became faster only after contact with workers from the colony. Subsequently, they dwelt in small cavities most likely representing empty brood cells or in spaces between the brood combs. As they aged from day 1 to 3 , virgin queens increased their activity and visited other nest regions outside the brood area. From day 5 to 9 , virgin queens moved quickly inside the nest and sheltered in corners and among honey pots and brood cells. Only the older workers, characterized by darker body pigmentation, showed aggression toward 5-9 days old virgin queens.
These workers contacted the abdomen and head of the virgin queen with their antennae and then used their mandibles to attack her, with some workers holding the legs and wings, while others decapitated her.

\section{Analysis of cuticular hydrocarbons}

Analysis of CHs of $M$. scutellaris queens showed a total of 52 peaks and around 103 compounds, including linear, and methyl and dimethyl branched alkanes, alkenes, and alkadienes with 23-41 carbon atoms (Table 1). CH differed significantly between the queen categories [PERMANOVA, Pseudo- $\mathrm{F}_{2,5}=22.410, \quad$ Unique $\quad$ Permutation $=275$, $\mathrm{P}(\mathrm{MC})=0.001]$. The pairwise comparison showed significant differences in the $\mathrm{CH}$ profiles between newly emerged virgin and 8-day-old virgin queens $[t=2.707$, Unique Permutation $=10, \mathrm{P}(\mathrm{MC})=0.020$, average dissimilarity distance $=66.78$ ], between newly emerged virgin queen and physogastric queens $[t=5.785$, Unique Permutation $=10, \quad \mathrm{P}(\mathrm{MC})=0.002, \quad$ average dissimilarity distance $=31.987]$ and between 8-day-old virgin and physogastric queens $[t=6.221$, Unique Permutation $=10$, $\mathrm{P}(\mathrm{MC})=0.002$, average dissimilarity distance $=43.075]$. These results are supported by a visual assessment of NMDS plot patterns using the Bray-Curtis distance (Fig. 1).

Newly emerged queens showed $\mathrm{C}_{23}$ and $\mathrm{x}-\mathrm{C}_{31: 1}$ as main compounds. The 8-day-old virgin queens showed $\mathrm{C}_{25}$, $\mathrm{x}-\mathrm{C}_{27: 1}, \mathrm{C}_{27}$, and $\mathrm{x}-\mathrm{C}_{31: 1}$ in high amounts. Physogastric queens exhibited a high diversity of branched alkanes, mainly those with 33 and 35 carbons, which were c.a. $50 \%$ of the CHs. Virgin queens had higher amounts of alkanes and alkenes than physogastric ones, and alkadienes were found only in virgin queens.

\section{Discussion}

Our findings show that the aggressive behavior of $M$. scutellaris workers against virgin queens is dependent on virgin queen age. Specifically, workers only attack queens aged at least 5 days or older, the age at which queens become highly active, sheltering in colony corners and honey pots. Similar results have been observed in another bee species. These include $M$. compressipes (Sakagami and Oniki 1963), M. quadrifasciata (Sakagami et al. 1965; Silva et al. 1972), M. marginata (Kleinert and ImperatrizFonseca 1994; Kleinert 2005), M. beecheii (van Veen et al. 1999; Wenseleers et al. 2004), and M. favosa (Koedam et al. 1995). The ages at which virgin queens are attacked, however, vary according to species.

During the attack against the M. scutellaris virgin queens, workers are focused on the head and thorax of the queen, unlike $M$. beecheii workers that attack the 
Table 1 Relative abundance (mean \pm standard error) of cuticular hydrocarbons in queens of Melipona scutellaris

\begin{tabular}{|c|c|c|c|c|c|c|}
\hline \# & Compound & RI & Physogastric & Newly emerged & Eight day old virgin & Diagnostic ion $(\mathrm{m} / \mathrm{z})$ \\
\hline 1 & $\mathrm{C}_{23}$ & 2300 & $2.76 \pm 0.24$ & $14.51 \pm 2.65$ & $2.93 \pm 0.26$ & 324 \\
\hline 2 & $\begin{array}{l}\text { 11-Me C } 23 \\
9-\mathrm{Me} \mathrm{C}_{23}\end{array}$ & 2330 & $0.32 \pm 0.01$ & $0.28 \pm 0.12$ & $0.06 \pm 0.03$ & $\begin{array}{l}169,197 \\
141,225\end{array}$ \\
\hline 3 & $\mathrm{C}_{24}$ & 2400 & $0.60 \pm 0.05$ & $0.28 \pm 0.12$ & $0.13 \pm 0.04$ & 338 \\
\hline 4 & $\mathrm{x}-\mathrm{C}_{25: 1}$ & 2473 & $0.56 \pm 0.11$ & $4.40 \pm 0.72$ & $1.61 \pm 0.21$ & 350 \\
\hline 5 & $\mathrm{C}_{25}$ & 2500 & $9.06 \pm 0.17$ & $6.05 \pm 1.13$ & $8.54 \pm 0.41$ & 352 \\
\hline 6 & $\begin{array}{l}13-\mathrm{Me} \mathrm{C}_{25} \\
11-\mathrm{Me} \mathrm{C}_{25} \\
9-\mathrm{Me} \mathrm{C}_{25}\end{array}$ & 2530 & $2.76 \pm 0.24$ & $0.43 \pm 0.19$ & $0.55 \pm 0.09$ & $\begin{array}{l}197 \\
169,225 \\
141,253\end{array}$ \\
\hline 7 & 5-Me $\mathrm{C}_{25}$ & 2548 & $0.51 \pm 0.02$ & $1.19 \pm 0.20$ & $0.43 \pm 0.18$ & 85,309 \\
\hline 8 & $\mathrm{x}-\mathrm{C}_{27: 1}$ & 2671 & $0.91 \pm 0.13$ & $3.59 \pm 0.70$ & $5.98 \pm 0.85$ & 378 \\
\hline 9 & $\mathrm{C}_{27}$ & 2700 & $2.92 \pm 0.03$ & $3.08 \pm 0.62$ & $9.03 \pm 1.09$ & 380 \\
\hline 10 & $\begin{array}{l}13-\mathrm{Me} \mathrm{C}_{27} \\
11-\mathrm{Me} \mathrm{C}_{27} \\
9-\mathrm{Me} \mathrm{C}_{27}\end{array}$ & 2729 & $1.31 \pm 0.14$ & $0.69 \pm 0.05$ & $0.79 \pm 0.14$ & $\begin{array}{l}197,225 \\
169,253 \\
141,281\end{array}$ \\
\hline 11 & $5-\mathrm{Me} \mathrm{C}_{27}$ & 2749 & 0.07 & $1.18 \pm 0.11$ & $0.47 \pm 0.05$ & 85,337 \\
\hline 12 & $3-\mathrm{Me} \mathrm{C} 27$ & 2773 & - & $1.01 \pm 0.12$ & $0.58 \pm 0.02$ & 365 \\
\hline 13 & Unknown & 2781 & $0.68 \pm 0.02$ & - & - & 85,140 \\
\hline 14 & 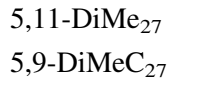 & 2781 & - & $0.15 \pm 0.04$ & $0.10 \pm 0.04$ & $\begin{array}{l}85,183,253,351 \\
85,155,281,351\end{array}$ \\
\hline 15 & $\mathrm{x}-\mathrm{C}_{29: 1}$ & 2873 & $0.87 \pm 0.10$ & $4.03 \pm 0.28$ & $4.36 \pm 0.24$ & 406 \\
\hline 16 & $\mathrm{C}_{29}$ & 2900 & $1.87 \pm 0.18$ & $1.85 \pm 0.29$ & $5.87 \pm 0.55$ & 408 \\
\hline 17 & $\begin{array}{l}13-\mathrm{Me} \mathrm{C}_{29} \\
11-\mathrm{Me} \mathrm{C}_{29} \\
9-\mathrm{Me} \mathrm{C}_{29}\end{array}$ & 2932 & $2.63 \pm 0.28$ & $2.43 \pm 0.32$ & $1.74 \pm 0.13$ & $\begin{array}{l}197,253 \\
169,281 \\
141,309\end{array}$ \\
\hline 18 & 7-Me C 29 & 2941 & $0.40 \pm 0.03$ & $2.70 \pm 0.35$ & $1.05 \pm 0.12$ & 113,337 \\
\hline 19 & $3-\mathrm{Me} \mathrm{C}_{29}$ & 2971 & - & $1.92 \pm 0.27$ & $0.84 \pm 0.25$ & 393 \\
\hline 20 & Unknown & 2981 & $0.61 \pm 0.01$ & - & - & - \\
\hline 21 & $\begin{array}{l}\text { 5,11- } \mathrm{DiMe}_{29} \\
5,9-\mathrm{DiMeC}_{29}\end{array}$ & 2981 & - & $0.61 \pm 0.06$ & $0.25 \pm 0.02$ & $\begin{array}{l}85,183,253,351 \\
85,155,281,351\end{array}$ \\
\hline 22 & $\mathrm{x}-\mathrm{C}_{31: 1}$ & 3085 & $6.91 \pm 0.40$ & $25.78 \pm 1.50$ & $23.74 \pm 1.67$ & 434 \\
\hline 23 & $\mathrm{C}_{31}$ & 3100 & $0.82 \pm 0.11$ & $0.60 \pm 0.05$ & $2.18 \pm 0.19$ & 436 \\
\hline 24 & $\begin{array}{l}15-\mathrm{Me} \mathrm{C} \mathrm{C}_{31} \\
13-\mathrm{Me} \mathrm{C} \mathrm{C}_{31} \\
11-\mathrm{Me} \mathrm{C} \mathrm{C}_{31} \\
\text { 9-Me C } 31\end{array}$ & 3135 & $5.52 \pm 0.33$ & $1.44 \pm 0.15$ & $2.42 \pm 0.30$ & $\begin{array}{l}225,253 \\
197,281 \\
169,309 \\
141,337\end{array}$ \\
\hline 25 & $\begin{array}{l}\text { 13,17--DiMeC } 31 \\
11,15-\mathrm{DiMeC}_{31}\end{array}$ & 3155 & $1.24 \pm 0.21$ & $0.04 \pm 0.03$ & $0.41 \pm 0.08$ & $\begin{array}{l}197,225,267,295 \\
169,239,253,323\end{array}$ \\
\hline 26 & $\begin{array}{l}\text { 7,17-DiMe } \mathrm{C}_{31} \\
\text { 7,15-DiMe } \mathrm{C}_{31} \\
\text { 7,13-DiMe C } \mathrm{C}_{31} \\
\text { 7,11-DiMe C } \mathrm{C}_{31}\end{array}$ & 3167 & $0.61 \pm 0.01$ & $0.10 \pm 0.08$ & $0.27 \pm 0.07$ & $\begin{array}{l}113,155,337,379 \\
113,183,309,379 \\
113,211,281,379 \\
113,239,253,379\end{array}$ \\
\hline 27 & $\begin{array}{l}\text { 16-Me C32 } \\
\text { 14-Me C32 } \\
12-\mathrm{Me} \mathrm{C} 32\end{array}$ & 3228 & $0.92 \pm 0.04$ & - & $0.06 \pm 0.05$ & $\begin{array}{l}239 \\
211,281 \\
183,209\end{array}$ \\
\hline 28 & Unknown & 3252 & $0.71 \pm 0.02$ & - & - & - \\
\hline 29 & $\mathrm{x}-\mathrm{C}_{33: 2}$ & 3255 & - & $2.00 \pm 0.58$ & $1.19 \pm 0.07$ & 460 \\
\hline 30 & $x-C_{33: 2}$ & 3263 & - & $1.21 \pm 0.39$ & $0.67 \pm 0.08$ & 460 \\
\hline
\end{tabular}


Table 1 continued

\begin{tabular}{|c|c|c|c|c|c|c|}
\hline \# & Compound & RI & Physogastric & Newly emerged & Eight day old virgin & Diagnostic ion $(\mathrm{m} / \mathrm{z})$ \\
\hline 31 & $\mathrm{x}-\mathrm{C}_{33: 1}$ & 3285 & $1.79 \pm 0.05$ & $4.01 \pm 0.17$ & $4.94 \pm 0.35$ & 462 \\
\hline \multirow[t]{4}{*}{32} & $17-\mathrm{Me} \mathrm{C}_{33}$ & 3335 & $11.66 \pm 0.05$ & $0.13 \pm 0.11$ & $2.26 \pm 0.35$ & 253 \\
\hline & $15-\mathrm{Me} \mathrm{C}_{33}$ & & & & & 225,281 \\
\hline & $13-\mathrm{Me} \mathrm{C} 33$ & & & & & 197, 309 \\
\hline & $11-\mathrm{Me} \mathrm{C}_{33}$ & & & & & 169,337 \\
\hline \multirow[t]{3}{*}{33} & 15,19-DiMe $\mathrm{C}_{33}$ & 3355 & $8.54 \pm 0.02$ & - & - & 225,295 \\
\hline & 13,17-DiMe $\mathrm{C}_{33}$ & & & & & $197,253,267,323$ \\
\hline & 11,15 -DiMe $\mathrm{C}_{33}$ & & & & & $169,239,281,351$ \\
\hline 34 & Unknown & 3408 & 0.32 & - & - & - \\
\hline \multirow[t]{6}{*}{35} & $17-\mathrm{Me} \mathrm{C}_{34}$ & 3424 & $1.88 \pm 0.03$ & - & - & 253,267 \\
\hline & $16-\mathrm{Me} \mathrm{C}_{34}$ & & & & & 239,281 \\
\hline & $15-\mathrm{Me} \mathrm{C}_{34}$ & & & & & 225,295 \\
\hline & $14-\mathrm{Me} \mathrm{C}_{34}$ & & & & & 211,309 \\
\hline & $13-\mathrm{Me} \mathrm{C}_{34}$ & & & & & 197, 323 \\
\hline & $12-\mathrm{Me} \mathrm{C}_{34}$ & & & & & 183,337 \\
\hline 36 & Unknown & 3445 & $1.24 \pm 0.05$ & - & - & - \\
\hline 37 & $x-C_{35: 2}$ & 3461 & - & $5.41 \pm 2.12$ & $2.34 \pm 0.98$ & 488 \\
\hline 38 & $x-C_{35: 2}$ & 3467 & - & $1.78 \pm 0.41$ & $0.93 \pm 0.33$ & 488 \\
\hline 39 & $x-C_{35: 1}$ & 3478 & - & $1.38 \pm 0.16$ & $0.72 \pm 0.07$ & 490 \\
\hline 40 & $\mathrm{x}-\mathrm{C}_{35: 1}$ & 3482 & $0.27 \pm 0.01$ & $1.12 \pm 0.24$ & - & 490 \\
\hline \multirow[t]{4}{*}{41} & $17-\mathrm{Me} \mathrm{C}_{35}$ & 3535 & $11.12 \pm 0.72$ & - & $0.61 \pm 0.11$ & 253,281 \\
\hline & $15-\mathrm{Me} \mathrm{C}_{35}$ & & & & & 225,309 \\
\hline & $13-\mathrm{Me} \mathrm{C}_{35}$ & & & & & 196, 337 \\
\hline & $11-\mathrm{Me} \mathrm{C}_{35}$ & & & & & 169,365 \\
\hline \multirow[t]{3}{*}{42} & 15,19-DiMe $\mathrm{C}_{35}$ & 3355 & $8.85 \pm 0.48$ & - & $0.11 \pm 0.09$ & $225,253,295,323$ \\
\hline & 13,17-DiMe $\mathrm{C}_{35}$ & & & & & $197,267,281,351$ \\
\hline & $11,15-\mathrm{DiMe} \mathrm{C}_{35}$ & & & & & $169,239,309,379$ \\
\hline \multirow[t]{6}{*}{43} & $17-\mathrm{Me} \mathrm{C}_{36}$ & 3626 & $1.00 \pm 0.07$ & - & - & 253,295 \\
\hline & $16-\mathrm{Me} \mathrm{C}_{36}$ & & & & & 239,309 \\
\hline & $15-\mathrm{Me} \mathrm{C}_{36}$ & & & & & 225,323 \\
\hline & $14-\mathrm{Me} \mathrm{C}_{36}$ & & & & & 211,337 \\
\hline & $13-\mathrm{Me} \mathrm{C}_{36}$ & & & & & 197,351 \\
\hline & $12-\mathrm{Me} \mathrm{C}_{36}$ & & & & & 183,365 \\
\hline 44 & Unknown & 3650 & $0.68 \pm 0.04$ & - & - & - \\
\hline 45 & $x-C_{37: 2}$ & 3655 & - & $1.18 \pm 0.05$ & $1.30 \pm 0.52$ & 516 \\
\hline 46 & $x-C_{37: 2}$ & 3661 & - & $1.14 \pm 0.16$ & $0.92 \pm 0.07$ & 516 \\
\hline 47 & $x-C_{37: 2}$ & 3668 & - & $0.76 \pm 0.33$ & $1.48 \pm 0.79$ & 516 \\
\hline 48 & $x-C_{37: 1}$ & 3690 & - & $0.67 \pm 0.23$ & $0.38 \pm 0.12$ & 518 \\
\hline \multirow[t]{4}{*}{49} & $17-\mathrm{Me} \mathrm{C}_{37}$ & 3735 & $2.65 \pm 0.25$ & $0.49 \pm 0.22$ & $1.18 \pm 0.12$ & 253,309 \\
\hline & $15-\mathrm{Me} \mathrm{C}_{37}$ & & & & & 225,337 \\
\hline & $13-\mathrm{Me} \mathrm{C}_{37}$ & & & & & 197, 365 \\
\hline & $11-\mathrm{Me} \mathrm{C}_{37}$ & & & & & 169,393 \\
\hline \multirow[t]{3}{*}{50} & 15,19-DiMe C 37 & 3755 & $3.69 \pm 0.35$ & - & $3.38 \pm 0.39$ & $225,281,295,351$ \\
\hline & 13,17-DiMe C 37 & & & & & $197,267,309,379$ \\
\hline & 11,15-DiMe $\mathrm{C}_{37}$ & & & & & $169,239,337,407$ \\
\hline
\end{tabular}


Table 1 continued

\begin{tabular}{|c|c|c|c|c|c|c|}
\hline$\#$ & Compound & RI & Physogastric & Newly emerged & Eight day old virgin & Diagnostic ion $(\mathrm{m} / \mathrm{z})$ \\
\hline \multirow[t]{6}{*}{51} & $17-\mathrm{Me} \mathrm{C}_{38}$ & 3826 & $0.05 \pm 0.04$ & $0.19 \pm 0.16$ & $1.08 \pm 0.20$ & 253,309 \\
\hline & $16-\mathrm{Me} \mathrm{C}_{38}$ & & & & & 239,323 \\
\hline & $15-\mathrm{Me} \mathrm{C}_{38}$ & & & & & 225,337 \\
\hline & $14-\mathrm{Me} \mathrm{C}_{38}$ & & & & & 211,351 \\
\hline & $13-\mathrm{Me} \mathrm{C}_{38}$ & & & & & 197,365 \\
\hline & $12-\mathrm{Me} \mathrm{C}_{38}$ & & & & & 183,393 \\
\hline \multirow[t]{3}{*}{52} & 15,19-DiMe $\mathrm{C}_{39}$ & 3955 & $0.77 \pm 0.04$ & $0.20 \pm 0.17$ & $2.04 \pm 0.21$ & $225,295,309,379$ \\
\hline & $13,17-\mathrm{DiMe} \mathrm{C}_{39}$ & & & & & $197,267,337,407$ \\
\hline & $11,15-\mathrm{DiMe} \mathrm{C}_{39}$ & & & & & $169,239,365,435$ \\
\hline
\end{tabular}

$C_{n}$ Number of carbon atoms in alkanes, $x$ - $C_{n: y}$ number of carbon atoms in alkenes or alkadienes; "x" denotes the double bond position, and "y" the number of unsaturation, for compounds with high molecular weight was not possible to assign the double-bond position, Me methyl, DiMe dimethyl, $R I$ retention index

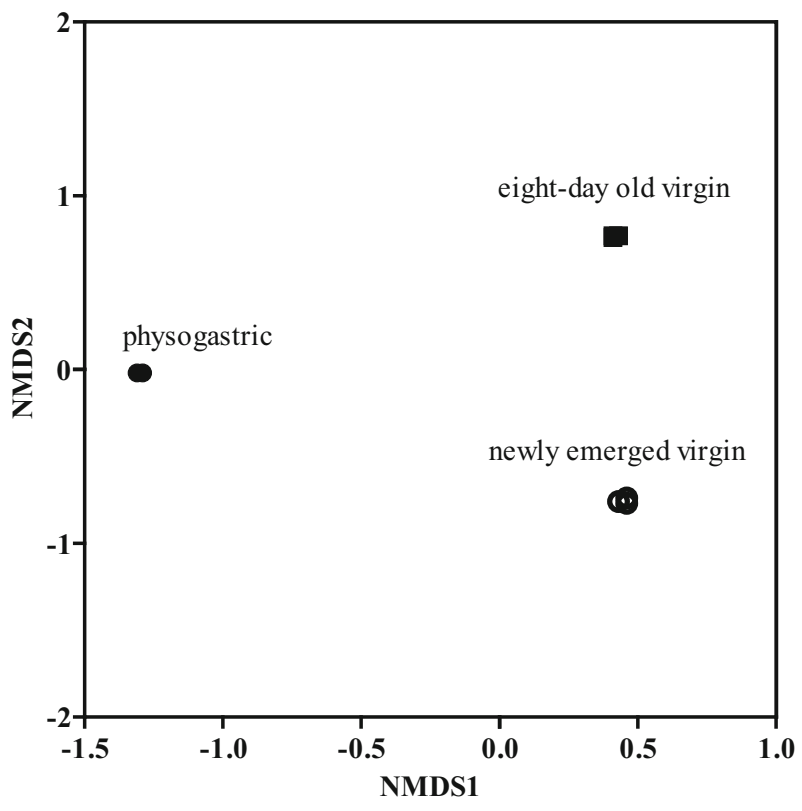

Fig. 1 Discrimination of queens of Melipona scutellaris based on cuticular hydrocarbon composition, using non-metric multi-dimensional scaling (NMDS) ordination based on Bray-Curtis distance

abdominal region (Jarau et al. 2009). Our data show that the abdominal region of $M$. scutellaris queens seems to be important for recognition, as workers engage in aggressive behavior only after contacting the abdomen of the virgin queen with their antennae. Class III unicellular glands occur dorsally on the abdomen of stingless bees and are more developed in queens than in workers, suggesting that gland secretions may have a pheromone function (Abdalla and Cruz-Landim 2002; Guerino and Cruz-Landim 2003). Moreover, the Dufour gland located at the abdominal edge in queen bees seems to be responsible for the production of cuticular hydrocarbons, which are important for recognition of queens by workers in the stingless bee M. bicolor (Abdalla et al. 2004).
Our PERMANOVA analysis shows that the cuticular hydrocarbons' profile differs between $M$. scutellaris virgin and physogastric queens in a clade isolated from newlyemerged and 8-day-old queens. Differences in cuticular hydrocarbon profiles between $M$. scutellaris physogastric and virgin queens may be a physiological change that occurs after mating, given that mating in insects has been associated with changes in the profile of these compounds (Cuvillier-Hot et al. 2001; Polerstock et al. 2002; Abdalla et al. 2003; Howard and Blomquist 2005; Hora et al. 2008; Nunes et al. 2009a; Oppelt and Heinze 2009; Everaerts et al. 2010; Izzo et al. 2010; Will et al. 2012).

In the social insects, the cuticle is not yet mature after the last change. The body cuticle is completely mature only in older individuals and the more abundant $\mathrm{CHs}$ are alkanes, followed by alkenes, alkadienes, and methyl alkenes (Elias-Neto et al. 2013; Falcon et al. 2014; Kather and Martin 2015). Our findings for the $\mathrm{CH}$ profiles in $M$. scutellaris virgin queens show differences from those reported for this stingless bee by Kerr et al. (2004), which were rich in tricosane contrasting with hentricontene as described here, which may be due to different $\mathrm{CH}$ extraction procedures, given that those authors only used the bee's wings.

Our findings show a different $\mathrm{CH}$ profile in 8-day-old $M$. scutellaris virgin queens, which may be a trigger for workers to kill the queens. The literature information about $\mathrm{CH}$ profile for virgin queens of different ages is scarce. Newly emerged queens and 2-day-old $M$. marginata virgin queens have similar profiles, but these are different from the 8 day old virgin queen profiles, which are more likely to be attacked by workers (Caliman 2008). Melipona scutellaris virgin queens have larger amounts of long-chain alkenes than physogastric queens, compounds that may play a pheromone role. A. mellifera workers sprayed with alkenes are more frequently attacked by their nest mates 
than those treated with alkanes (Dani et al. 2005). The alkenes in the body cuticle of M. scutellaris may be the trigger for workers to attack the virgin queens, because the double-bond position and the methyl groups are recognized by bees (Dani et al. 2005; Chaline et al. 2005; Kather and Martin 2015).

In the bumble bee Bombus terrestris, van Oystaeyen et al. (2014) claim that long chain hydrocarbons, likely pentacosane, function as queen pheromone, inhibiting ovary activation and/or oosorption in workers. However, Amsalem et al. (2015) stated that there is no experimental evidence that proves long chain alkanes affect worker reproduction. The $\mathrm{CH}$ profile in $M$. scutellaris physogastric queen with high amount of long chain and branched alkenes suggest its function as a reliable signal of queen presence in the colony.

$\mathrm{CH}$ profile differences between virgin and mated queens, and between sterile workers and reproductive queens have been reported in social insects (BonavitaCougourdan et al. 1991; Peeters et al. 1999; Cuvillier-Hot et al. 2001; Abdalla et al. 2003; Dietemann et al. 2013; Biseau et al. 2004; Oppelt and Heinze 2009; Nunes et al. 2010). M. bicolor and M. marginata physogastric queens have different $\mathrm{CH}$ profiles from virgin queens (Abdalla et al. 2003; Caliman 2008) and Friesella schrottkyi workers with active ovaries differ from workers with atrophied ovaries (Nunes et al. 2010). The influence of ovary activation in the $\mathrm{CH}$ profile has also been reported in ants (Peeters et al. 1999; Biseau et al. 2004).

In conclusion, our results show that recognition of virgin queens by $M$. scutellaris workers occurs at a median age of 7 days, and this timeframe matches changes in the behavior and cuticular hydrocarbon profiles of these bees. We suggest that $\mathrm{CHs}$ may be the trigger for virgin queen recognition by workers in the nest, resulting in attacks by workers on virgin queens, which may be subsequently killed.

Acknowledgements This research was supported by grants of Fundação de Amparo à Pesquisa de Minas Gerais-PRONEX EDT \#522/ 07 for JES, and Fundação de Amparo à Pesquisa do Estado de São Paulo \#2011-17708-0 and Conselho Nacional de Pesquisa \#3061032013-3 for JRT.

\section{References}

Abdalla FC, Cruz-Landim C (2002) Glândulas exócrinas das abelhas. Funpec, Ribeirão Preto

Abdalla FC, Jones GR, Morgan ED, Cruz-Landim C (2003) Comparative study of the cuticular hydrocarbon composition of Melipona bicolor Lepeletier, 1836 (Hymenoptera, Meliponini) workers and queens. Genet Mol Res 2:191-199

Abdalla FC, Jones GR, Morgan ED, Cruz-Landim C (2004) Chemical composition of the Dufour gland secretion in queens of Melipona bicolor (Hymenoptera, Meliponini). J Braz Chem Soc 15:621-625

Amsalem E, Orlova M, Grozinger CM (2015) A conserved class of queen pheromones? Re-evaluating the evidence in bumblebees (Bombus impatiens). Proc R Soc B 282:20151800

Anderson MJ (2005) PERMANOVA: a FORTRAN computer program for permutational multivariate analysis of variance. Department of Statistics, University of Auckland, New Zealand

Biseau JC, Passera L, Daloze D, Aron S (2004) Ovarian activity correlates with extreme changes in cuticular hydrocarbon profile in the highly polygynous ant, Linepithema humile. J Insect Physiol 50:585-593

Bonavita-Cougourdan A, Theraulaz G, Bagnères AG, Roux M, Pratte M, Provost E, Clement JL (1991) Cuticular hydrocarbons, social organization and ovarian development in a polistine wasp: Polistes dominulus Christ. Comp Biochem Physiol 100:667-680

Caliman MJF (2008) Caracterização do perfil de hidrocarbonetos cuticulares de operárias, rainhas virgens e rainhas fisogástricas de Melipona marginata Lepeletier, 1836 (Hymenoptera, Apinae, Meliponini). Dissertação de Mestrado, Universidade de São Paulo

Carlson DA, Offor II, El Messoussi S, Matsuyama K, Mori K, Jallon JM (1998) Sex pheromone of Glossina tachinoides: isolation, identification and synthesis. J Chem Ecol 24:1563-1574

Carlson DA, Geden CJ, Bernier UR (1999) Identification of pupal exuviae of Nasonia vitripennis and Muscidifurax raptorellus parasitoids using cuticular hydrocarbons. Biol Control 15:97-106

Chaline N, Sandoz JC, Martin SJ, Ratnieks FL, Jones GR (2005) Learning and discrimination of individual cuticular hydrocarbons by honeybees (Apis mellifera). Chem Sen 30:327-335

Cuvillier-Hot V, Cobb M, Malosse C, Peeters C (2001) Sex, age and ovarian activity affect cuticular hydrocarbons in Diacamma ceylonense, a queenless ant. J Insect Physiol 47:485-493

Dani FR, Jones GR, Corsi S, Beard R, Pradella D, Turillazzi S (2005) Nestmate recognition cues in the honey bee: differential importance of cuticular alkanes and alkenes. Chem Sens 30:477-489

Dietemann V, Peeters C, Liebig J, Thivet V, Hölldobler B (2013) Cuticular hydrocarbons mediate discrimination of reproductive and nonreproductive in the ant Myrmecia gulosa. Proc Natl Acad Sci USA 100:10341-10346

Elias-Neto M, Nascimento ALO, Bonetti AM, Nascimento FS, Mateus S, Garófalo CA, Bitondi MMG (2013) Heterochrony of cuticular differentiation in eusocial corbiculate bees. Apidologie 45:397-408

Engels W, Imperatriz-Fonseca V (1990) Caste development, reproductive strategies, and control of fertility in honey bees and stingless bees. In: Engels W (ed) Social insects: an evolutionary approach to castes and reproduction. Springer, Berlin, pp $167-230$

Everaerts C, Farine J, Cobb M, Ferveur J (2010) Drosophila cuticular hydrocarbons revisited: Mating status alters cuticular profiles. PLoS One 5:e9607

Falcon T, Ferreira-Caliman MJ, Nunes FMF, Tanak ED, Nascimento FS, Bitondi MMG (2014) Exoskeleton formation in Apis mellifera: Cuticular hydrocarbons profiles and expression of desaturase and elongase genes during pupal and adult development. Insect Biochem Mol 50:68-81

Ferreira-Caliman MJ, Nascimento FS, Turatti IC, Mateus S, Lopes NP, Zucchi R (2010) The cuticular hydrocarbons profiles in the stingless bee Melipona marginata reflect task-related differences. J Insect Physiol 56:800-804

Guerino AC, Cruz-Landim C (2003) Ocorrência e morfologia das glândulas tegumentares do abdome de algumas abelhas 
(Hymenoptera: Apidae): Um estudo comparado. Neotrop Entomol 32:261-267

Hora RR, Ionescu-Hirsh A, Simon T, Delabie J, Robert J, Fresneau D, Hefetz A (2008) Postmating changes in cuticular chemistry and visual appearance in Ectatomma tuberculatum queens (Formicidae: Ectatomminae). Naturwissenschaften 95:55-60

Howard RW, Blomquist GJ (2005) Ecological, behavioural, and biochemical aspects of insect hydrocarbons. Annu Rev Entomol 50:371-393

Imperatriz-Fonseca VL, Zucchi R (1995) Virgin queens in stingless bee (Apidae, Meliponinae) colonies: a review. Apidologie 26:231-244

Izzo A, Wells M, Huang Z, Tibbetts E (2010) Cuticular hydrocarbons correlate with fertility, not dominance, in a paper wasp, Polistes dominulus. Behav Ecol Sociobiol 64:857-864

Jarau S, Van Veen J, Aguilar I, Ayasse M (2009) Virgin queen execution in the stingless bee Melipona beecheii: the sign stimulus for worder attacks. Apidologie 40:496-507

Kather R, Martin SJ (2015) Evolution of cuticular hydrocarbons in the Hymenoptera: A meta-analysis. J Chem Ecol 41:871-883

Kerr WE, Zucchi R, Nakadaira JT, Butolo JE (1962) Reproduction in the social bees (Hymenoptera: Apidae). J New York Entomol Soc 70:267-276

Kerr WE, Jungnickel H, Morgan ED (2004) Workers of the stingless bee Melipona scutellaris are more similar to males than to queens in their cuticular compounds. Apidologie 35:611-618

Kleinert AMP (2005) Colony strength and queen replacement in Melipona marginata (Apidae: Meliponini). Braz J Biol 65:469-476

Kleinert AMP, Imperatriz-Fonseca VL (1994) Virgin queen refuges in colonies of Melipona marginata (Apidae, Meliponinae). Braz J Biol 54:247-251

Koedam D (1999) Production of queens, workers and males in the stingless bee Melipona favosa (Apidae: Meliponinae): pattern in time and space. Neth J Zool 49:289-302

Koedam D, Aguilar MI, Sommeijer MJ (1995) Social interactions of gynes and their longevity in queenright colonies of Melipona favosa (Apidae: Meliponinae). Neth J Zool 45:480-494

Legendre P, Legendre L (2003) Numerical ecology, 2nd edn. Elsevier, Amsterdam

Michener CD (1974) The social behavior of the bees. Harvard University Press, Cambridge

Monnin T (2006) Chemical recognition of reproductive status in social insects. Ann Zool Fen 43:515-530

Nelson DR, Dillwith JW, Blomquist GJ (1981) Cuticular hydrocarbons of the house fly, Musca domestica. Insect Biochem 11:187-197

Nunes TM, Turatti ICC, Lopes NP, Zucchi R (2009a) Chemical signals in the stingless bee, Frieseomelitta varia, indicate caste, gender, age and reproductive status. J Chem Ecol 35:1172-1180

Nunes TM, Turatti ICC, Mateus S, Nascimento FS, Lopes NP, Zucchi $\mathrm{R}$ (2009b) Cuticular hydrocarbon in the stingless bee Schwarziana quadripunctata (Hymenoptera, Apidae, Meliponini): differences between colonies, castes and age. Genet Mol Res 8:589-595

Nunes TM, Morgan ED, Drijfhout FP, Zucchi R (2010) Caste-specific cuticular lipids in the stingless bee Friesella schrottkyi. Apidologie 41:579-588

Nunes TM, Mateus S, Favaris AP, Amaral MFZJ, von Zuben LG, Closoki GC, Bento JMS, Oldroyd BP, Silva R, Zucchi R, Silva DB, Lopes NP (2014) Queen signals in a stingless bee: suppression of worker ovary activation and spatial distribution of active compounds. Sci Rep 4:7449
Oppelt A, Heinze J (2009) Mating is associated with immediate changes of the hydrocarbon profile of Leptothorax gredleri ant queens. J Insect Physiol 55:624-628

Peeters C, Monnin T, Malosse C (1999) Cuticular hydrocarbons correlated with reproductive status in a queenless ant. Proc R Soc Lond B 266:1323-1327

Polerstock AR, Eigenbrode SD, Klowden MJ (2002) Mating alters the cuticular hydrocarbons of female Anopheles gambiae sensu stricto and Aedes aegypti (Diptera: Culidae). J Med Entomol 39:545-552

Pomonis JG (1989) Cuticular hydrocarbons of the screwworm, Cochliomyia hominivorax (Diptera: Calliphoridae). Isolation, identification and quantification as a function of age, sex and irradiation. J Chem Ecol 15:2301-2317

Sakagami SF, Oniki Y (1963) Behaviour studies of the stingless bees, with special reference to the oviposition process. I Melipona compressipes manaosensis Schwarz J Fac Sci Hokkaido Univ Ser VI Zool 15:300-318

Sakagami SF, Montenegro MJ, Kerr WE (1965) Behaviour studies of the stingless bees, with special reference to the oviposition process. V. Melipona quadrifasciata anthidioides Lepeletier. J Fac Sci Hokkaido Univ Ser VI Zool 15:578-607

Santos DE, Souza EA, Vieira CU, Zanuncio JC, Serrão JE (2015) Morphology of mandibular and intramandibular glands in workers and virgin queens of Melipona scutellaris. Apidologie 46:23-34

Santos-Filho PS, Alves DA, Eterovic A, Imperatriz-Fonseca VL, Kleinert AMP (2006) Numerical investment in sex and caste by stingless bees (Apidae: Meliponini): a comparative analysis. Apidologie 37:207-221

Silva DLN, Zucchi R, Kerr WE (1972) Biological and behavioural aspects of the reproduction in some species of Melipona (Hymenoptera, Apidae, Meliponinae). Anim Behav 20:123-132

Sommeijer MJ, De Bruijn LLM, Meeuwsen FJAJ, Martens EP (2003) Natural patterns of caste and sex allocation in the stingless bees Melipona favosa and M. trinitalis related to worker behavior. Insect Soc 50:38-44

Sousa CS, Serrão JE, Bonetti AM, Amaral IMR, Kerr WE, Maranhão AQ, Ueira-Vieira C (2013) Insights into the Melipona scutellaris (Hymenoptera, Apidae, Meliponini) fat body transcriptome. Gen Mol Biol 36:292-297

Van Den Dool H, Kratz PD (1963) A generalization of the retention index system including linear temperature programmed gasliquid partition chromatography. J Chromatogr A 11:463-471

Van Oystaeyen A, Oliveira RC, Homan L, van Zweden JS, Romero C, Oi CA, d'Ettorre P, Khalesi M, Billen J, Wäckers F, Millar JG, Wenseleers T (2014) Conserved class of queen pheromones stops social insect workers from reproducing. Science 343:287-290

Van Veen JW, Sommeijer MJ, Aguilar MI (1999) Behavioural development and abdomen inflation of gynes and newly mated queens of Melipona beecheii (Apidae, Meliponinae). Insect Soc 46:361-365

Wenseleers T, Hart AG, Ratnieks FLW, Quezada-Euàn JJG (2004) Queen execution and caste conflict in the stingless bee Melipona beecheii. Ethology 110:725-736

Will S, Delabie JHC, Heinze J, Ruther J, Oetller J (2012) Cuticular lipid profiles of fertile and non-fertile Cardiocondyla ant queens. J Insect Physiol 58:1245-1249

Wossler TC, Jones GE, Allsopp MH, Hepburn R (2006) Virgin queen mandibular gland signals of Apis mellifera capensis change with age and affect honeybee worker responses. J Chem Ecol 32:1043-1056 